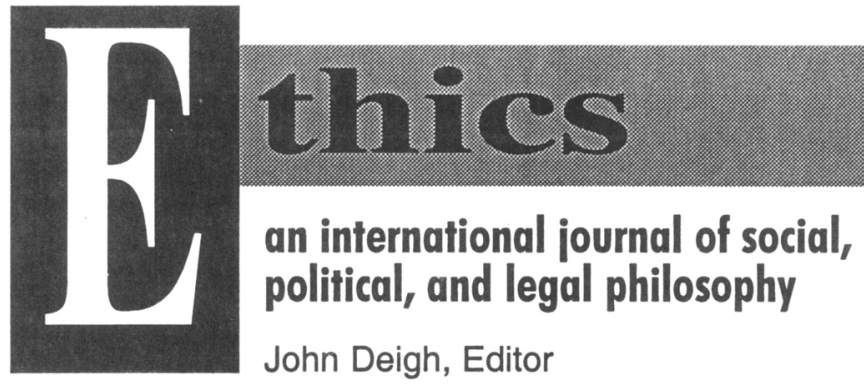

Published quarterly by The University of Chicago Press

\title{
Purpose and Scope
}

Founded in 1890, Ethics is an international journal of moral, political, and legal philosophy. It presents scholarly work from a variety of disciplines and intellectual perspectives, including philosophy, social and political theory, law, and economics. Taking a cross-cutting approach, the journal aims to bring theory and its applications to bear on contemporary moral issues. In addition, Ethics offers about 200 review essays, survey articles, book reviews, and book notes per volume.

\section{Special Features}

Ethics publishes symposia and special issues that examine particular topics in depth through the contribution of distinguished scholars. Recent examples:

Martha Nussbaum's Political Philosophy, articles by Louise Anthony, Hilary Charlesworth, Richard Arneson, Richard Mulgan, and Martha Nussbaum

Symposium on John Rawls's Law of Peoples, articles by Charles Beitz and Allen Buchanan

Christine Korsgaard's Creating the Kingdom of Ends, articles by Hannah Ginsborg, Paul Guyer, J. B. Schneewind, and Christine Korsgaard Physician-Assisted Suicide, articles by Judith Jarvis Thompson, Dan W. Brock, Paul J. Weithman, Gerald Dworkin, F. M Kamm, J. David Velleman, and Ezekiel J. Emanuel

Trust, articles by Karen Jones, Russell Hardin, and Lawrence C. Becker

\section{APA members save 20\%}

Regular one-year subscription rates/membership rates: Individuals $\$ 35.00$; Students $\$ 25.00$ (with copy of valid ID), APA Individual Members $\$ 29.00$, Institutions $\$ 99.00$. Outside USA, add $\$ 6.00$ for postage. Visa and MasterCard payments accepted. To order, send check, purchase order, or complete credit card information to the address below.

\section{The University of Chicago Press}

Journals Division, SSOSA, P.O. Box 37005, Chicago, IL 60637

Order online at $h$ ttp://www.journals.uchicago.edu/Ethics 


\title{
LAW AND SOCIETY
}

NEW FROM CHICAGO

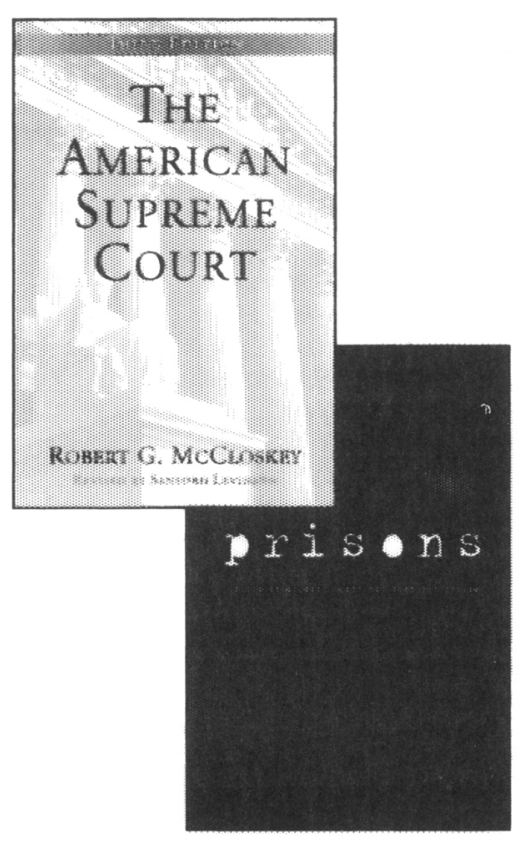

\author{
The American Suprene Coumt \\ Robert G. Mocloskey \\ Third Edition \\ Revised by Sanford Levinson
}

First published more than four decades ago, Robert MeCloskey's classic work on the Supreme Courts wole in construcring the U.S. Constitution has incroduced generations of studens wo the workings of our anarion's highest court. Sanford Levinson brings this new edition inw the twenty-first century, revising the last two chapress, which cover the events of the past forry years, and updaring the book's prefiace, coda. chronology, and bibliographical asery.

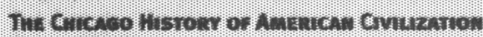
pat 51400

\section{Preisons}

Crime and Justice, Volume 26

Edited by Milchael Tonry and Joan Petersilla

Prisow provides a comprehensive overviews of policy isstes and research developments concerning prisons and imprisonment with chaptes by Afred Blumstein and Allen Beck, Joan Petersilia, Anthony Botroms. Douglas MeDonald, and others.

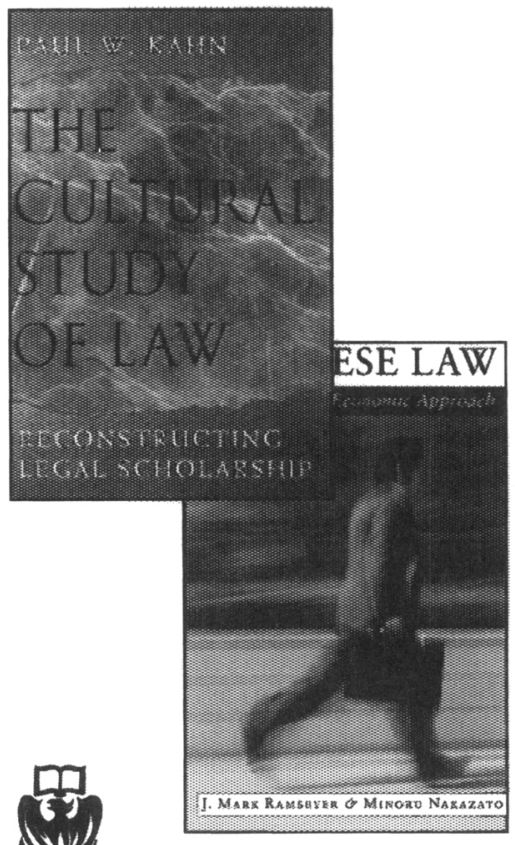

Paree 5330.00

\section{Now in paper}

The cutrueat Studr of Law Reconstructing Legal Scholarship

Paul W. Kahn

"Kahn. offers the first full csamination of what it means to conduct a modern medllocrual inquiry ino the cuive of law. Charting the way for die developmear. of a new inedlocsual discipline, he advocates an appreach that stands oumide lav's nommative framework and looks a liw as a way or lite nither than a ser of

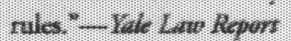

\section{Pireir 316.00}

Now in paper JPAines Liv

\section{An Economic Approach}

1. Mark Damseyer and Minoru Nalazato

"This is a lively and licid inrodicrion to lapance lav. 1. For those who are not Cimiliar with economic analsie of the law, this book conid well be an cye-open. es. . The audions heve many inceresting and insight. ful things to sor about the unique fearires of comporate governance in Japan and about anergers and cakeover." - Koochang Kin, Conbilidgr Law Jownal

The University of Chicago Press 1427 East 6oth Street, Chicago, IL 60637 www.press.uchicago.edu

\section{Srupies in Law and Economics} PAirer 520.00 


\section{The University of Chicago Press}

\section{Journals and Annual Series}

American Journal of Education

The American Journal of Human Genetics

员 American Journal of Sociology

口 The American Naturalist

‥ The Astronomical Journal

The Astrophysical Journal

ㅁ. The Astrophysical Journal Supplement Series

Classical Philology

믈 Clinical Infectious Diseases

Comparative Education Review

Crime and Justice

Critical Inquiry

․ Current Anthropology

Economic Development and Cultural Change

The Elementary School Journal

Ethics: An International Journal of Social,

Political, and Legal Philosophy

History of Religions

International Journal of American

Linguistics

口 International Journal of Plant Sciences Isis

Journal of the American Musicological Society

Journal of British Studies

The Journal of Business

D Journal of Consumer Research: An Interdisciplinary Quarterly
․ㅡㄹ The Journal of Geology

․ The Journal of Infectious Diseases Journal of Labor Economics The Journal of Law \& Economics

The Journal of Legal Studies

$\square$ The Journal of Modern History Journal of Near Eastern Studies

@ Journal of Political Economy The Journal of Religion Law \& Social Inquiry The Library Quarterly Modern Philology Ocean Yearbook Osiris Philosophy of Science

פ Physiological and Biochemical Zoology

D. Public Opinion Quarterly

D Publications of the Astronomical Society of the Pacific

The Quarterly Review of Biology

Signs: Journal of Women in Culture and Society

Social Service Review

Supreme Court Economic Review

The Supreme Court Review

Winterthur Portfolio

Electronic editions available

\section{The University of Chicago Press}

Journals Division

P. 0. . B.8. 378073

Q.1.

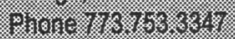

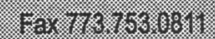

H.

Committed to scholaty excellence hn print and onhine

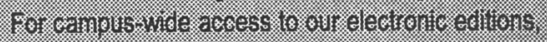

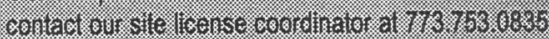

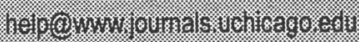




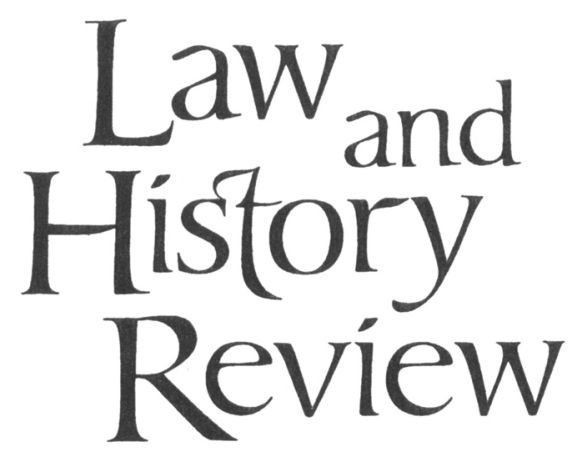

The official journal of the American Society for Legal History, Law and History Review is the leading American journal in its field. Articles on American, English, European, and ancient legal history attract readers from a broad range of academic and professional fields, including history, cultural studies, classics, and law. A large portion of each issue is devoted to reviewing important new books on legal and related topics.

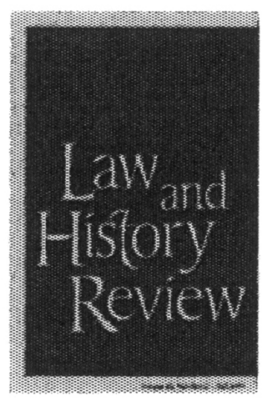

\section{Subscription Rates:}

Individuals: $\$ 50.00$; Institutions: $\$ 65.00$ (add $\$ 10.00$ for international surface mail) Subscription includes membership in the American Society for Legal History

Issued Spring, Summer, and Fall

"The best place to find out what an exciting field legal history has become. I read every issue with pleasure and a sense of discovery." - Robert W. Gordon, Professor of Law, Yale Law School

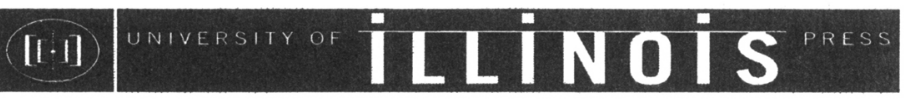

1325 South Oak Street

Champaign, IL 61820

(217) 333-8935; FAX: (217) 244-8082

www.press.uillinois.edu/journals/lhr.html 


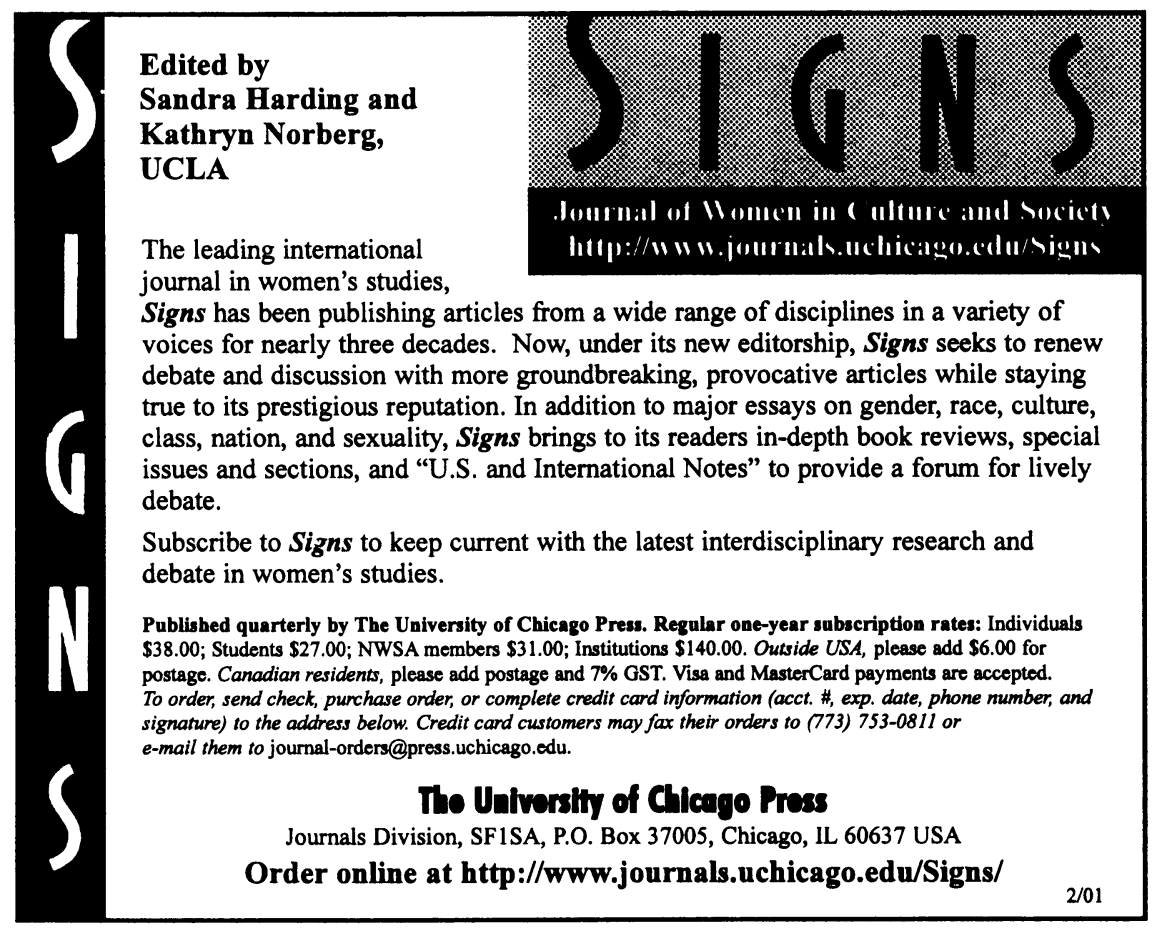

\section{STATEMENT OF OWNERSHIP, MANAGEMENT AND CIRCULATION \\ (Required by 39 U.S.C. 3685)}

1. Publication title: Law and Social Inquiry: Journal of the American Bar Foundation

2. Publication number: $0036-1170$

3. Filing date: September 30, 2000

4. Issue frequency: Quarterly

5. No. of issues published annually: 4

6. Annual subscription price: $\$ 68.00$

7. Complete mailing address of known office of publication: $\mathbf{5 7 2 0}$ South Woodlawn Ave., Chicago, Cook, IL 60637-1603

8. Complete mailing address of the headquarters or general business offices of the publishers: 5720 South Woodlawn Ave., Chicago, Cook, II 60637-1603

9. Full names and complete mailing addresses of publisher, editor, and managing editor:

Publisher: The University of Chicago Press, 5720 South

Woodlawn Ave., Chicago, IL 60637-1603

Editor: Victoria Saker-Woeste, and John Hagan, American Bar Foundation, 750 North Lake Shore Drive, Chicago, IL 606114403

Managing Editor: None

10. Owner: American Bar Foundation, 750 North Lake Shore Drive, Chicago, IL 60611

11. Known bondholders, mortgagees, and other security holders owning or holding 1 percent or more of total amount of bonds, mortgages or other securities: None

12. The purpose, function, and nonprofit status of this organization and the exempt status for Federal income tax purposes have not changed during preceding 12 months

13. Publication name: Law and Social Inquiry: Journal of the American Bar Association

14. Issue date for circulation data below: Spring 2000
15. Extent and nature of circulation:

A

a. Total number copies printed

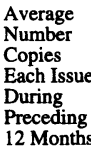

Actual

Number

Copies of

Single Issue

Published

Preceding Nearest to

$2,426 \quad 2,422$

b. Paid circulation:

. Paid Outside-county

Subscriptions

2. Paid In-county Subscriptions

3. Sales through dealers

and carriers, street

vendors and counter sales

4. Mail subscription

c. Total paid and/or requested

circulation

$\begin{array}{rr}1,608 & 1,469 \\ 0 & 0\end{array}$

140

68

d. Free distribution by mail (samples, complimentary, and other free copies)

1. Outside-county

2. In-county Subscriptions

3. Mail subscription

1,676

1,469

e. Free distribution outside the mail

f. Total free distribution (sum of d \& e) 49

g. Total distribution (sum of c \& f) 1,724

h. Copies not distributed: $\quad 702$

i. Total (sum of $\mathrm{g} \& \mathrm{~h}$ ) $\quad 2,426$

j. Percent paid and/or Requested Circulation

$97 \%$

49

0

0

49

1,658

764

2,422

$97 \%$

16. This Statement of Ownership will be printed in the Winter 2001 issue of this publication.

17. I certify that all information furnished on this form is true and complete. I understand that anyone who furnishes false or misleading information on this form or who omits material or information requested on the form may be subject to criminal sanctions (including fines and imprisonment) and/or civil sanctions (including multiple damages and civil penalties). 


\section{The Smart Subscription}

Selze this opportunity to cement your position at the forefront of your lield : subscribe to this journal now for $15 \%$ off the regular rate. (See order form on reverse.)

Challenge your ideas with the latest research avallable in each issue. The provocative and discursive content spans the gamut of trends, theories, commentary, and methods of our academic community

Save $50 \%$ on a complete set of back issues. See order form on reverse, or order online.

\section{The University of Chicago Press http://www.journals.uchicago.edu/}

\section{Law \& Social Inquiry}

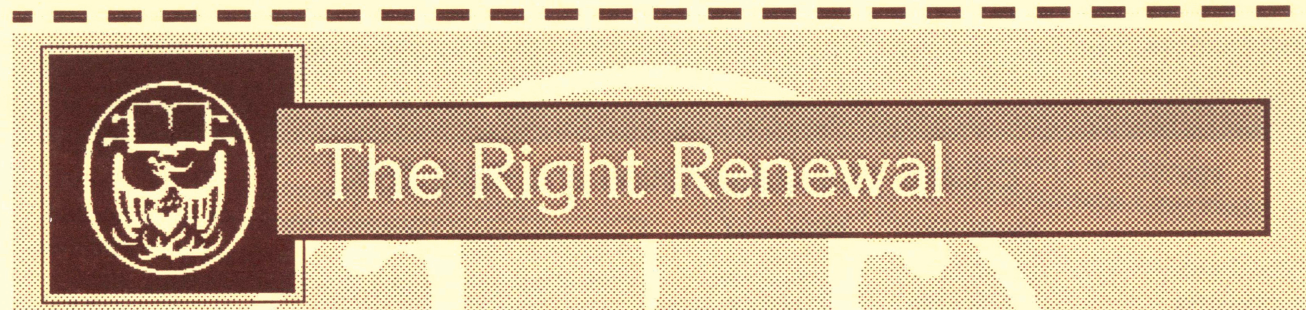

Maintain your position at the forefront of your field with a renewal to this oumal. (See order form on reverse.)

Don't interrupt your connection with the latest research avallable in each issue . Recall the provocative and discursive content that spans the gamut of trends, theories, commentary, and methods of our academic community.

Check the malling label on this issue-your subscription may. expire sooner than you think!

Save $50 \%$ on a complete set of back issues. See order form on reverse, or order online.

\section{The University of Chicago Press} http:/www.journals.uchicago.edu/

\section{Law \& Social Inquiry}




\section{Law \& Social Inquiry}

Enter a new subscription and save $25 \%$ !

$\begin{array}{lll} & \text { New } & \text { Renewal } \\ \square \text { Individuals } & \square \$ 27.00 & \square \$ 36.00 \\ \square \text { Institutions } & \square 51.00 & \square 68.00 \\ \square \text { Academics* } & \square 21.75 & \square 29.00\end{array}$

*For college/university faculty and students.

Outside USA: please add $\$ 6$ for postage.

Canadian residents: please add $7 \%$ GST.

Back issues: remaining issues (vols. 19-24) at $50 \%$ off (LSI-SET):

$\$ 115.00$ Individuals $\$ 207.00$ Institutions

Outside USA: please add $75 \notin$ per issue for postage.

Canadian residents: please add $7 \%$ GST.

Payment Options
Fax credit card orders to (773) 753-0811.
$\square$ Charge $\square$ MasterCard $\square$ Visa
Account no.
Expiration date
Signature
Phone number (
$\square$ Payment enclosed (U.S. currency only)

Name Phone (__

Address $\operatorname{Fax}($

City/State/Zip/Country E-mail

Visit our Web site at http://www.journals.uchicago.edu/LSI/

For special savings on two and three year rates, please direct inquiries to address listed below. Please send your order to the University of Chicago Press, Journals Division, P.O. Box 37005, Chicago, IL 60637 USA.

\section{Law \& Social Inquiry}

Enter a new subscription and save $25 \%$ !

$\begin{array}{lll} & \text { New } & \text { Renewal } \\ \square \text { Individuals } & \square \$ 27.00 & \square \$ 36.00 \\ \text { Institutions } & 51.00 & \square 68.00 \\ \square \text { Academics* }^{*} & \square 21.75 & \square 29.00\end{array}$

${ }^{*}$ For college/university faculty and students.

Outside USA: please add $\$ 6$ for postage.

Canadian residents: please add 7\% GST.

Back issues: remaining issues (vols. 19-24) at $50 \%$ off (LSI-SET):

$\$ 115.00$ Individuals $\square \$ 207.00$ Institutions

Outside USA: please add $75 €$ per issue for postage.

Canadian residents: please add $7 \%$ GST.

Payment Options
Fax credit card orders to (773) 753-0811.
$\square$ Charge $\square$ MasterCard $\square$ Visa
Account no.
Expiration date
Signature
Phone number (_
$\square$ Payment enclosed (U.S. currency only)

Name Phone (_

Address

Fax

City/State/Zip/Country

E-mail

Visit our Web site at http://www.journals.uchicago.edu/LSI/

For special savings on two and three year rates, please direct inquiries to address listed below. Please send your order to the University of Chicago Press, Journals Division, P.O. Box 37005, Chicago, IL 60637 USA. 


\section{American Bar Foundation}

\section{BOARD OF DIRECTORS}

President, Kenneth J. Burns, Jr., of the Illinois Bar • Vice-President, Jacqueline Allee, of the Florida Bar • Secretary, Carrie Menkle-Meadow, Georgetown University Law Center • Treasurer, M. Peter Moser, of the Maryland Bar

Hon. Marvin E. Aspen, United States District Court, Northern District of Illinois • James H. Carter, of the New York Bar • Roberta Cooper Ramo, of the New Mexico Bar • Rachelle DesVaux, of the Florida Bar • Robert O. Hetlage, of the Missouri Bar - Herma Hill Kay, University of California at Berkeley School of Law - David K.Y. Tang, of the Washington Bar • David E. VanZandt, of the Illinois Bar

ex officio:

William G. Paul, President, American Bar Association - Martha W. Barnett, President-Elect, American Bar Association • Robert J. Grey, Jr., Chair, House of Delegates, American Bar Association • Earle F. Lasseter, Treasurer, American Bar Association • Jane H. Barrett, President, American Bar Endowment • John L. Carey, Chair, The Fellows of the American Bar Foundation • The Honorable Jerome Farris, Vice-Chair, The Fellows of the American Bar Foundation • Zona F. Hostetler, Secretary, The Fellows of the American Bar Foundation

\section{OFFICERS}

Bryant G. Garth, Director

Joanne Martin, Associate Director

\section{RESEARCH FELLOWS}

Jonathan D. Casper, Ph.D. Yale University

John L. Comaroff, Ph.D. University of London

Stephen Daniels, Ph.D. University of Wisconsin

Shari S. Diamond, Ph.D. Northwestern University;

J.D. University of Chicago

Bryant G. Garth, J.D. Stanford University; Ph.D.

European University Institute

Austan Goolsbee, Ph.D. Massachusetts Institute of

Technology

John Hagan, Ph.D., University of Alberta

Terence C. Halliday, Ph.D. University of Chicago

James J. Heckman, Ph.D. Princeton

Carol A. Heimer, Ph.D. University of Chicago

John P. Heinz, LL.B. Yale University

Bonnie Honig, Ph.D. Johns Hopkins University

Steven D. Levitt, Ph.D. Massachusetts Institute of Technology
Tracey Meares, J.D., University of Chicago

Elizabeth Mertz, J.D. Northwestern University; Ph.D. Duke University

Robert L. Nelson, J.D., Ph.D. Northwestern University

Laura Beth Nielsen, J.D., Ph.D., University of California at Berkeley

Annelise Riles, Ph.D. University of Cambridge; J.D. Harvard University

Robert J. Sampson, Ph.D. State University of New York at Albany

Susan P. Shapiro, Ph.D. Yale University

Christopher L. Tomlins, Ph.D. Johns Hopkins

Victoria Saker Woeste, Ph.D. University of California, Berkeley

\section{LIAISON RESEARCH SERVICES PROGRAM}

Joanne Martin, M. M. Northwestern University, J.D. Loyola University

Barbara A. Curran, LL.B. University of Connecticut, LL.M. Yale University 


\section{Law \& Social Inquiry}

\section{Volume 26, Number 1, Winter 2001}

\section{SYMPOSIUM: Law, Religion, and Identity}

Symposium Introduction:

Law and Religion

WINNIFRED FALLERS SULLIVAN AND FRANK E. REYNOLDS

Law, Religion, and "Public Health" in the Republic of Brazil

PAUL CHRISTOPHER JOHNSON

Law and the Image of a Nation: Religious Conflict and Religious

Freedom in a Brazilian Criminal Case

ERIC W. KRAMER

The Oppressed, the Suspect, and the Citizen: Subjectivity in Competing

Accounts of Political Violence SUSAN BIBLER COUTIN

A Conversation with Tibetans? Reconsidering the Relationship between

Religious Beliefs and Secular Legal Discourse REBECCA R. FRENCH

Positivists and Buddhists: The Rise and Fall of Anglo-Burmese

Ecclesiastical Law ANDREW HUXLEY

\section{REVIEW SECTION SYMPOSIUM}

The Common Place of Law

Out of the Ordinary: Law, Power, Culture, and the Commonplace NAOMI MEZEY

Strategizing the Street: How Law Matters in the Lives of Women in the Street-Level Drug Economy KAY LEVINE AND VIRGINIA MELLEMA

\section{REVIEW ESSAYS}

David M. Rabban and the Libertarian Tradition That Time Forgot CLYDE SPILLENGER

Why Laws Work Pretty Well, but Not Great: Words and Rules in Legal

Interpretation LAWRENCE M. SOLAN

Essentialism and Universalism in Gay Rights Philosophy: Liberalism Meets Queer Theory CARLOS A. BALL

\section{BOOK NOTES}

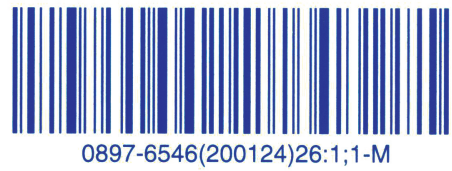

